\title{
Laakbaar gedrag berispt
}

\section{Bas Sorgdrager}

Een Regionaal Tuchtcollege doet in een tuchtzaak uitspraak over een tweetal klachten. Het komt neer op miskenning wat de functie van (her) registratie is en onvoldoende professionaliteit bij het hanteren van het beroepsgeheim.

\section{Klacht 1: Registratie laten verlopen}

De arts, verweerder in deze zaak, geeft zich gedurende om en nabij zeven jaar ten onrechte uit als bedrijfsarts. De arts blijkt bij de zitting onvoldoende in te zien dat (her)registratie onder meer staat voor waarborging van kwaliteit. Het college weegt bij zijn oordeel mee dat verweerder al sinds 2011 niet meer in het BIG-register geregistreerd staat als bedrijfsarts en dus meerdere oproepen en/of mogelijkheden moet hebben gehad om de deregistratie ongedaan te maken. Verweerder voert aan dat hij door privéomstandigheden niet in staat is geweest zijn (her) registratie te behouden dan wel te behalen. Echter, bij de beoordeling van dit klachtonderdeel gaat het om het feit dat verweerder ten onrechte een specialistentitel voert. De reden waarom verweerder niet als bedrijfsarts is geregistreerd acht het college in dit kader niet relevant. Het Regionaal Tuchtcollege concludeert dat verweerder heeft gehandeld in strijd met het verbod op het voeren van een beschermde specialistentitel zoals neergelegd in artikel 17 Wet BIG. Het college weegt daarbij mee dat verweerder ter zitting heeft bevestigd zich sinds zijn deregistratie als bedrijfsarts in 2011 uit te geven als bedrijfsarts en dat tot op heden nog steeds te doen. Verweerder heeft er geen, althans onvoldoende, blijk van gegeven dat hij beseft dat dit uiterst onwenselijk en zelfs bij wet verboden is. Door zich ten onrechte uit te geven voor bedrijfsarts schaadt hij het vertrouwen dat in het algemeen kan worden verleend aan deze beroepsgroep.

\section{Klacht 2: Beroepsgeheim geschonden}

Verweerder heeft na zijn onderzoek verslag aan werkgever en werknemer uitgebracht. Uit het aan de werkgever toegezonden evaluatieverslag blijkt dat verweerder de werkgever van klaagster heeft geïnformeerd over haar thuissituatie, over het feit dat klaagster gesprekken heeft (gehad) met een psycholoog, alsmede over de WIA-status van klaagsters echtgenoot.
Het Regionaal Tuchtcollege overweegt dat de bedrijfsarts een vertrouwensband met de werknemer heeft en voor de informatieverstrekking aan de werkgever gebonden is aan het beroepsgeheim ingevolge de wetgeving. Dat impliceert dat hij alleen die gegevens mag verstrekken die de werkgever daadwerkelijk nodig heeft om te bepalen of de werknemer recht heeft op loondoorbetaling, en informatie in het kader van verzuimbegeleiding en re-integratie van de patiënt/werknemer. De bedrijfsarts moet de patiënt/ werknemer vooraf informeren over deze informatieverstrekking. De bedrijfsarts verstrekt niet zonder meer (sociaal-)medische gegevens aan de werkgever, maar zet de verkregen gegevens om in een beschrijving van uitsluitend de noodzakelijke en relevante informatie voor de werkgever. Alleen met uitdrukkelijke toestemming van de werknemer kan de bedrijfsarts (aanvullende) informatie aan de werkgever verstrekken. Uiteraard is het aan de werknemer zelf óf en welke (medische) informatie hij aan de werkgever of leidinggevende over zijn ziekte of persoonlijke omstandigheden wenst te geven. Uit het aan de werkgever toegezonden evaluatieverslag blijkt dat hierin meer opgenomen is dan conform het vorenstaande is toegestaan. Dat de werkgever, volgens verweerder, al op de hoogte was van de thuissituatie van klaagster en hem uitdrukkelijk had verzocht de thuissituatie van klaagster in zijn oordeel te betrekken, doet daaraan niet af. Verweerder heeft weliswaar zijn excuses aangeboden voor het feit dat het woord psycholoog in het evaluatieverslag is vermeld, maar hij heeft er geen blijk van gegeven dat hij met het - op verzoek van de werkgever - verstrekken van informatie over de thuissituatie eveneens zijn beroepsgeheim heeft geschonden. Verweerder lijkt zich aldus onvoldoende bewust van de reikwijdte van zijn beroepsgeheim.

\section{Uitspraak Regionaal Tuchtcollege}

Beide klachten zijn gegrond. De arts krijgt een berisping, waarbij het ten onrechte voeren van de titel bedrijfsarts hem zwaar wordt aangerekend.

Kijk voor de volledige tekst van deze uitspraak op www.tuchtrecht.nl>Gezondheidszorg, en zoek met zaaknummer 17402. Wilt u reageren? Stuur een mail naar TBVredactie@bsl.nl 